\begin{tabular}{|c|c|}
\hline \multirow{3}{*}{ 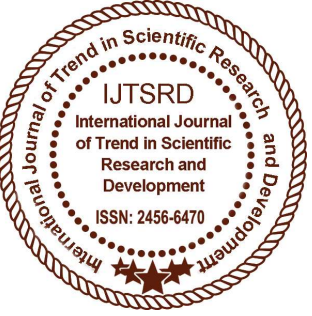 } & $\begin{array}{l}\text { International Journal of Trend in Scientific } \\
\text { Research and Development (IJTSRD) }\end{array}$ \\
\hline & International Open Access Journal \\
\hline & ISSN No: 2456 - 6470 | www.ijtsrd.com | Volume - 2 | Issue - 5 \\
\hline
\end{tabular}

\title{
Identification of Leaf Spot Causing Pathogen Through ITS Sequencing in Clove and it's Management Using Bioagents, Botanicals and Chemicals
}

\author{
S. Aravindasamy ${ }^{1}$, Dr. R. Kannan ${ }^{2}$, Dr. M. Jayasekhar ${ }^{3}$, \\ Dr. R. Swarnapriya ${ }^{4}$, Dr. V. Ramamoorthy ${ }^{5}$ \\ ${ }^{1}$ M.Sc. (Ag.) Student, ${ }^{2,3}$ Professor (Plant Pathology), \\ ${ }^{4}$ Professor (Horticulture), ${ }^{5}$ Assistant Professor (Plant Pathology) \\ Tamil Nadu Agricultural University, Department of Plant Pathology, \\ Agricultural College and Research Institute, Killikulam, Vallanad, Tamil Nadu, India
}

\section{ABSTRACT}

Clove tree is mostly grown in the hilly tracts of Tamil Nadu and Kerala. The leaves of clove seedling and grown up trees were frequently infected with leaf spot disease. The pathogen inciting leaf spot disease was isolated and identified - as Colletotrichumgloeosporioides based on ITS1-5.8s, ITS-2 rDNA sequence analysis. The present study was concerned with bio agents, fungicides and botanicals which were tested against $C$. gloeosporioides. Among the bio agents, Trichodermaharzianum was found effective with $72.22 \%$ growth inhibition. Among the botanicals garlic extract at $5 \%$ and $10 \%$ concentration levels was found to be effective with 56.66 and $62.66 \%$ growth inhibition respectively followed by ginger extract 48.88 and $49.66 \%$ growth inhibition. Among chemicals,propiconazole $(0.1 \%$ and $0.2 \%)$ was found to be the most effective fungicide in inhibiting $100 \%$ growth of $C$. gloeosporioides followed by hexaconazole with 87.44 and $88.55 \%$ growth inhibition at $0.1 \%$ and $0.2 \%$ respectively.

Keywords: Clove, Colletotrichumgloeosporioides, ITS sequencing, bio agents, botanicals and fungicides.

\section{INTRODUCTION}

The clove of commerce is the aromatic, dry, fully grown, but un-opened flower buds of the clove tree (Syzygiumaromaticum) (Family: Myrtaceae). Clove grows well in rich loamy soils of the humid tropics and can be grown successfully in the red soils of the midlands of Kerala as well as in the hilly terrain of Western Ghats at higher elevations in Tamil Nadu. Leaf spot disease incidence in clove seedlings and grown up trees is a serious concern. Black to brown water soaked lesions appeared on the leaves with circular yellow halo margin. In advanced stage, these spots enlarged, coalesced and resulted in bigger patches. Severely affected leaves wither, droop down and dry up. In nursery seedlings, die back symptoms were observed. Twigs were infected as the symptoms extended from the leaves through petioles. The affected branches stand without leaves or only with young leaves at tips. The objective of the present study was i) to isolate and identify the pathogen associated with the leaf spot disease of clove. ii) to screen potential bio control agents, botanicals and fungicides for the inhibition of the leaf spot causing pathogen under in vitro condition.

\section{Materials and methods:}

Isolation and Identification of leaf spot causing pathogen.

The infected leaves were collected from five different locations of farmer's clove field during survey. Isolation was done in a Laminar-air-flow chamber under aseptic condition. Infected host tissues were selected from the advancing margin of the lesion, cut into small pieces, placed in mercuric chloride $\left(\mathrm{HgCl}_{2}\right)$ solution ( 0.1 per cent) for $1 \mathrm{~min}$ then washed with 
sterile distilled water three times. The surface sterilized pieces were placed on a Potato Dextrose Agar (PDA) plate and incubated at room temperature $28 \pm 2^{\circ} \mathrm{C}$. After 3 to 5 days, the fungal growth associated with the pieces was examined and aseptically transferred to PDA slants and plates. Vegetative and reproductive structures were examined under the microscope for identification of the microorganism.

\section{Identification of Virulent isolate of Colletotrichum} spp.

Different isolates were characterized and virulent isolate was selected based on their growth, asexual reproduction and pathogen city. The virulent isolate was identified based on morphological, phenotypic and molecular techniques.

\section{Confirmation of Colletotrichumspp based on} molecular techniques

Isolation of total genomic DNA from Colletotrichumspp.

Total genomic DNA was isolated from C. gloesporioides as described by Lee et al., (1988) for fungi with slight modifications. The mycelium was grown in PDA broth for 2-3 days until the mycelial growth covers the liquid broth. The mycelium was collected and filtered through cheese cloth. Hundred $\mathrm{mg}$ of the mycelium was immersed in $95 \%$ ethanol for 5 min. The mycelium was squeezed and dried to remove the excess ethanol and was ground using sterile pestle and mortar with a small pinch of sterilized sand. Then $0.75 \mathrm{ml}$ of $2 \mathrm{X}$ CTAB buffer was added and mixed well. The $750 \mu \mathrm{l}$ mixture was transferred to sterile $2 \mathrm{ml}$ centrifuge tubes and incubated at $65^{\circ} \mathrm{C}$ for $25-30 \mathrm{~min}$. To this mixture 750 $\mu 1$ of chloroform was added, vortexed and incubated for $5 \mathrm{~min}$. The contents were centrifuged at 14,000 rpm for $15 \mathrm{~min}$. The supernatant aqueous solution was collected and transferred to a new $1.5 \mathrm{ml}$ tube and equal amount of iso-propanol was added to the aqueous solution and incubated at $-20^{\circ} \mathrm{C}$ for 1 hour or overnight for precipitation of DNA. The sample was centrifuged at $14,000 \mathrm{rpm}$ for $15 \mathrm{~min}$ to pellet the nucleic acids. The supernatant was discarded and pellet was washed 2 times with $70 \%$ ice cold ethanol and dried or kept in water bath for $5 \mathrm{~min}$ at $37^{\circ} \mathrm{C}$. Finally, the isolated DNA was resuspended in $50 \mu \mathrm{l}$ of distilled water or $1 \mathrm{X}$ TE buffer and stored at $-20^{\circ} \mathrm{C}$ for further use. To verify the quality of isolated DNA, $2.5 \mu 1$ of total DNA solution was resolved in the $1 \%$ agarose gel electrophoresis.
ITS sequencing of $C$. gloeosporioides.

A PCR was performed in a total volume of $50 \mu \mathrm{l}$ using Emerald Amp ${ }^{\circledR}$ GT PCR master mix using genomic DNA ofC. gloeosporioides as a template. The intermediate $5.8 \mathrm{~S}$ ribosomal gene along with ITS1 and ITS2 region were amplified using the primers ITS1 and ITS4 with the PCR conditions of initial denaturation at $94^{\circ} \mathrm{C}$ for $5 \mathrm{~min} ; 35$ cycles of denaturation at $94^{\circ} \mathrm{C}$ for $30 \mathrm{sec}$, annealing temperature at $50^{\circ} \mathrm{C}$ for $30 \mathrm{sec}$ and extension at $72^{\circ} \mathrm{C}$ for $60 \mathrm{sec}$, and a final extension at $72^{\circ} \mathrm{C}$ for $10 \mathrm{~min}$. The reaction was carried out in aEppendorfmastercycler gradient PCR machine. The PCR products were resolved by electrophoresis in $1 \%$ agarose gel. The PCR products were purified using FavorPrep GEL/ PCR purification kit and sequenced at Eurofins genomics India Pvt. Ltd. Bangalore.

The Primers used for amplification of ITS region were ITS1 - 5' TCCGTAGGTGAACCTGCGG 3' (forward primer)

ITS4 - 5' TCCTCCGCTTATTGATATGC3' (reverse primer)

\section{Sequencing of ITS and}

Colletotrichumgloeosporioides

identification of

bioinformatics analysis.

The obtained DNA sequences were trimmed at 5'and 3 ' region where the sequencing chromatogram was not clear. Then DNA sequence, in which clear chromatogram obtained was made in Fasta format. This was used as input sequence (Query sequence) in nucleotide blast analysis program at NCBI database. The output data retrieved from the bioinformatics were analysed and, the organism showing major score was considered as the closely related species to the test fungus used in the study.

Effect of the growth of C.gloeosporioides- Dual culture technique (Fleming et al., 1975).

The antagonistic effect of Pseudomonas sp. and Bacillus sp. was tested against the C.gloeosporioides. Nine mm PDA culture disc of the pathogen was cut individually from seven day old culture. This was placed at one side on the sterilized PDA previously plated in sterilized Petri dish. The pathogen was allowed to grow for three days. Actively growing Pseudomonas sp. and Bacillus sp. cultures were separately streaked on the opposite side of the pathogen after three days. Culture disc of 
Trichoderma spp. were placed on the opposite side of the plates. Three replications for each treatment and suitable controls were maintained. The plates were incubated at room temperature $\left(28 \pm 2^{\circ} \mathrm{C}\right)$ for seven day. The mean diameter of the mycelial growth was measured and the results were expressed in terms of per cent inhibition of the mycelium over control (Vincent, 1947).

$\mathbf{C}-\mathbf{T}$

$\mathbf{I}=\underline{\mathbf{x} 100 W h e r e, ~ I}=$ Per cent inhibition over control, C

$\mathrm{C}=$ Growth in control, $\mathrm{T}=$ Growth in treatment.

Effect of botanicals on the growth of C.gloeosporioides- poisoned food technique

The botanical extract solutions were mixed with PDA medium to obtain 5 and 10 per cent concentrations. Nine $\mathrm{mm}$ actively growing PDA culture disc of C.gloeosporioides was cut by means of a sterilized cork borer and placed at the centre of the medium. The plates were incubated at room temperature $(28 \pm$ $2^{\circ} \mathrm{C}$ ). PDA without botanical extract served as control. Three replications were maintained for individual treatment. The radial growth of the mycelium was measured in treatments on $10^{\text {th }}$ day after inoculation when the fungus was fully grown $(9 \mathrm{~cm})$ in the control plate. The mean diameter of the mycelial growth of the pathogens was recorded and the results were expressed in terms of per cent inhibition of mycelium over control.

\section{In vitro efficacy of fungicides against the pathogens} - Poisoned food technique

Under in vitro condition, different fungicides viz., Hexaconazole $5 \%$ EC(Contaf), Propiconozole 25\% EC (Tilt ), Metalaxyl $4 \%+$ Mancozeb $64 \%$ WG (Ridomil) , Mancozeb 75\% WP (Indo Fil M-45), Tebuconazole $50 \%+$ trifloxystrobin $25 \%$ (Nativo), Azoxystrobin $23 \%$ EC ( Amistar ), Carbendazim 12 $\%+$ Mancozeb 63\% WP (SAAF ) and Carbendazim $75 \%$ WP (Bavistin) were tested against the C.gloeosporioides. The desired concentrations were obtained by adding appropriate amount of stock solution of fungicides to potato dextrose agar taken in conical flask and then transferred to petriplates and repeated thrice for each treatment. Potato dextrose agar without fungicides served as control. Each plate was inoculated with a $9 \mathrm{~mm}$ mycelial disc of the pathogen taken from 7 day old culture. The inoculated plates were incubated at room temperature. The colony diameter was recorded and per cent inhibition in each treatment over control was calculated using the formula (Vincent, 1947) as described above.

\section{Results:}

Isolation and Identification of the pathogen Colletotrichumsp by molecular technique

The pathogen was isolated from the infected portion of the clove leaf collected from five different places using potato dextrose agar (PDA) medium. The pathogen was sub cultured by single hyphal tip method. Initially the colour of the mycelium was found to be white, later changed to black. The pathogen was taken 7- 10 days to cover the entire Petri dish.

The virulent isolate $\mathrm{Cg} 3$ was identified by morphological and culture characters at genus level and finally confirmed by molecular technique. ITS sequence analysis is one of the commonly used molecular methods for the identification of fungi at species level. DNA from Colletotrichumspp was isolated using CTAB method. Single band of intact genomic DNA was visualised on the agarosegel. ITS region of $C$. gloeosporioides was amplified with primers ITS 1 and ITS 4 using a thermo cycler and the products produced were visualised as a single band in agarose gel strained with Ethidium bromide. The size of the PCR fragments was approximately $550 \mathrm{bp}$ length. (Fig.1)

\section{DNA sequence analysis of ITS region}

ITS products of the C. gloeosporioides obtained by PCR were cleaned with PCR cleanup kit to remove the residual primers, polymerase and salts in the PCR product according to the protocol mentioned in the manufacturer kit. Cleaned up PCR product was sequenced at Euro fins genomic Pvt, Ltd. The full length of ITS sequences obtained for $C$. gloeosporioides were BLAST searched in the database of National Centre for Biotechnology information (NCBI). When the ITS sequence of the $C$. gloeosporioides was BLAST searched in the NCBI data base, the output data showed matching sequences of C. gloeosporioides. Thus the virulent $C$. gloeosporioides isolate used in the present study was confirmed as C. gloeosporioides.

In vitro evaluation of bio control agents against C.gloeosporioides- (Dual culture technique)

There were significant differences among the two fungal bio agents. T.harzianum recorded the maximum fungal growth inhibition (72.22 \%) 
followed by T.viride(67.44\%). Among the bacterial bio agents, Bacillus sp. (55.22\%) was found superior followed by $P$. fluorescens1 (40.77\%). Bacillussp, was found to be more effective in mycelial growth inhibition than $P$. fluorescens 1 . Fungal bioagents $T$. viride, T. harzianum isolates were found superior than bacterial bio control agents. (Table 1)

\section{Efficacy of botanicals on the growth of} C.gloeosporioides in vitroat5 $\%$ and $10 \%$ Concentrations

Among the ten plant extracts tested at 5 per cent concentration, maximum percent inhibition of mycelial growth $(56.66 \%)$ was recorded in garlic bulb extract which was significantly superior to all other treatments, followed by ginger rhizome extract (48.88 \%).The neem leaf extractrecordedminimal mycelial growth inhibition(7.11\%) of $C$. gloeosporioides. At 10 per cent concentration of plant extracts, maximum inhibition $(62.66 \%)$ of mycelial growth was recorded in garlic bulb extract followed by ginger rhizome extract $(49.66 \%)$. The least mycelial inhibition $(12.66 \%)$ was found in neem leaf extract. (Table 2 )

\section{In vitro evaluation of fungicides against} C.gloeosporioidesat $0.1 \%$ and $0.2 \%$ concentrations (Poison food technique)

Totally eight fungicides were tested at 0.1 and 0.2 per cent concentrations against the mycelial growth of $C$. gloeosporioides under in vitro. Maximum inhibition of pathogen growth was observed in plates incorporated with propiconazole (100\%) and hexaconazole $(87.4 \%$ and $88.5 \%)$ at 0.1 and 0.2 per cent concentrations and were significantly superior to other fungicides and followed by Carbendazim $12 \%$ + Mancozeb 63\% WP (86.6\% and 87.4\%). The least per cent inhibition of fungus was recorded in Carbendazim $50 \% \mathrm{WP}$ ( $4.11 \%$ and $4.44 \%$ ). (Table 3)

\section{Discussion:}

The isolate of the pathogen was brought from the locality and maintained as pure culture. Based on morphological, cultural characters and pathogen city the pathogen was identified as C. gloeosporioides. Similar studies were conducted byPrashanth (2007).

The bio control agent, T.harzianumisolate was best in inhibiting the mycelial growth of $C$. gloeosporioides followed by $T$. viridew here as $P$. fluorescens exhibited the lowest inhibition against
C.gloeosporioides as far as the present study is concerned .In this present study $T$. viride and $T$. harzianum isolates were found to be effective in inhibiting the mycelial growth of $C$. gloeosporioides while $T$. asperellum showed low inhibition followed by Bacillus cereus (52.52.4\%). Significant mycoparasitism between $T$. viride, $T$. harzianum and $T$. asperellum and anthracnose fungus leading to lysis of pathogen hyphae was also observed in vitro. This is agreement with the findings of Mandhare et al.,(1996); Prashanth et al., (2008) ; Devamma et al., (2012) and Pandey et al., (2012). Saju et al., (2012) reported that Pseudomonassp was the most effective antagonist to inhibit mycelial growth of $C$. gloeosporioides. In this present study, bulb extract of garlic was found effective against $C$. gloeosporioides followed by rhizome extract of ginger. Three plant extracts namely Nagadhale, Simarouba and Lantana leaf extract showed more than 60 per cent inhibition of mycelial growth at $20 \%$ concentration. Effectiveness of Neem, Tulsi, Lantana and Pongamia leaf extract against $C$. gloeosporioides was also studied by many authoursviz., Jadhav et al., (2008) ; Vinod et al., (2009); Watve et al., (2009) ; Mukherjee et al., (2011) and Ademe et al., (2013).

In this present study, hexaconazole and propiconazole even at $0.1 \%$ concentration were found effective against C.gloeosporioides. Most of the fungicides viz., Hexaconazole, Propiconazole, Penconazole, Tebuconazole, Carbendazim, Azoxystrobin, Difenoconazole, Thifluzamide, Trifluoxystrobin inhibited maximum mycelial growth at $0.2 \%$ but decreased with reduced concentration such as 0.05 and 0.1 per cent. (Patel (2009) ; Vinod et al., (2009); Devamma et al., (2012) ; Pandey et al., (2012) and Saju et al., (2012).

\section{References:}

1. Fleming, H., Etchells, J., \& Costilow, R. (1975). Microbial inhibition by an isolate of Pediococcus from cucumber brines. Applied Microbiology, 30(6), 1040-1042.

2. Vincent, J. (1947). Distortion of fungal hyphae in the presence of certain inhibitors. Nature, 159(4051), 850 .

3. Mandhare, V., Pawar, B., \& Kulkarni, S. (1996). Efficacy of fungicides against fruit spot of pomegranate. Pestology, 20(2), 19-20.

4. Ademe, A., Ayalew, A., \&Woldetsadik, K. (2013). Evaluation of antifungal activity of plant 
International Journal of Trend in Scientific Research and Development (IJTSRD) ISSN: 2456-6470

extracts against papaya anthracnose (Colletotrichumgloeosporioides).Journal of Plant Pathology \& Microbiology, 4(10), 1.

5. Devamma, M. N., Rajkumari, J. P., \& Devi, P. S. (2012).Fungicide compatible potential biocontrol agents against Colletotrichumgloeosporioides Penz. causing mango anthracnose. Current Biotica, 5(4), 454-464.

6. Jadhav, S., Diwakar, M., Sawant, U., \&Kadam, J. (2008). Management of leaf spot disease of Kokum (Garciniaindica) incited by Colletotrichumgloeosporioides Penz. Journal of Plant Disease Sciences, 3(2), 193-196.

7. Mukherjee, A., Khandker, S., Islam, M., \&Shahid, S. B. (2011). Efficacy of some plant extracts on the mycelial growth of Colletotrichumgloeosporioides. Journal of the Bangladesh Agricultural University, 9(1), 43-48.

8. Pandey, A., Yadava, L., Mishra, R., Pandey, B., Muthukumar, M., \&Chauhan, U. (2012).Studies on the incident and pathogenesis of Colletotrichumgloeosporioides penz. causes anthracnose of mango. International Journal of Science and Nature, 3(2), 220-232.

9. Patel, D. (2009). Chemical management of fruit spot of pomegranate caused by Colletotrichumgloeosporioides Penz. And Sacc. Indian Phytopathology, 62(2), 252-253.

10. Prashanth, A. (2007). Investigation on anthracnose (Colletotrichumgloeosporioides (Penz.) Penz. And Sacc. of pomegranate (Punicagranatum L.). M. Sc.(Agri.) Thesis, Uni. Agric. Sci., Dharwad (India), 100-160.

11. Prashanth, A., Sataraddi, A. R., Naik, M., Patil, M., \&Patil, R. S. (2008). Evaluation of fungicides, bio agents and botanicals against pomegranate anthracnose. Indian Journal of Plant Protection, 36(2), 283-287.

12. Saju, K., Deka, T., Gupta, U., Biswas, A., \&Sudharshan, M. (2012).In vitro evaluation of bio control agents, botanicals and fungicides against Colletotrichumgloeosporioides infecting large cardamom.Plant Disease Research, 27(1), 49-53.

13. Vinod, T., \&Benagi, V. (2009).Studies on the cultural and nutritional characteristics of Colletotrichumgloeosporioides, the causal organism of papaya anthracnose. Karnataka Journal of Agricultural Sciences, 22(4), 787-789.
14. Watve, Y., Diwakar, M., \&Kadam, J. (2009). An evaluation of some bio agents and plant extracts against leaf spot of Jatropha caused by Colletotrichumgloeosporioides Penz. Journal of Plant Disease Sciences, 4(1), 95-98.

\section{Fig.1 Isolation of gDNA and amplification ITS region from Colletotrichum sp.}

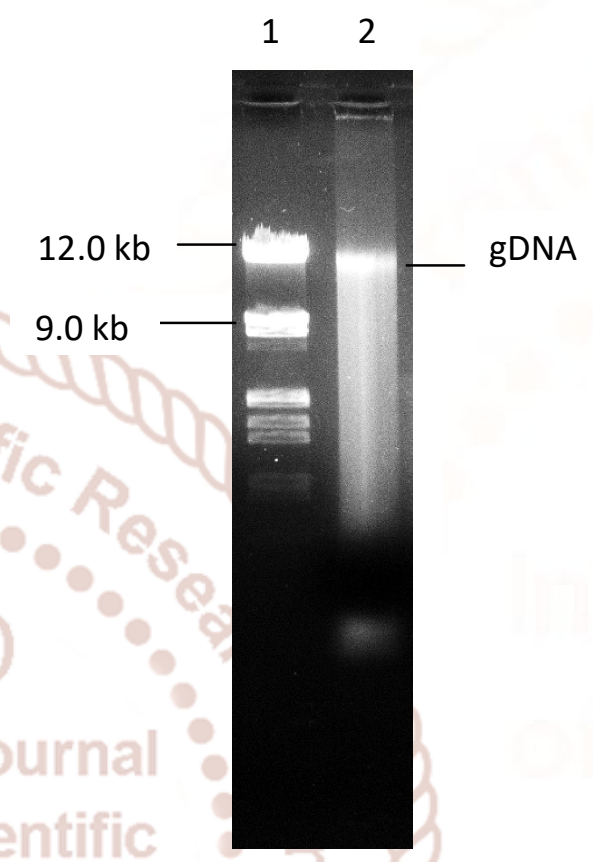

Lane 1. Lambda Ladder

Lane 2. Colletotrichum sp.

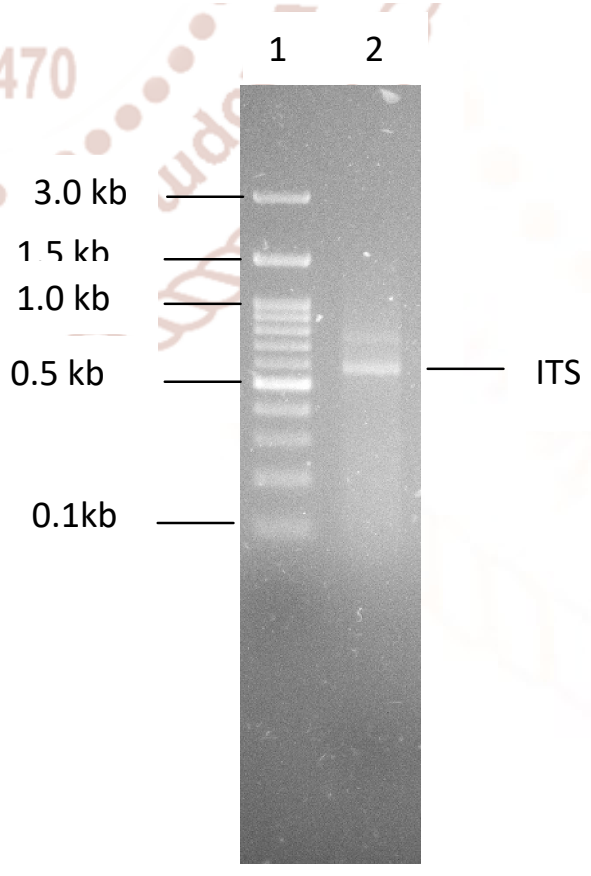

Lane 1.100 bp Ladder

Lane 2. Colletotrichum sp. 
International Journal of Trend in Scientific Research and Development (IJTSRD) ISSN: 2456-6470

Table1. In vitro evaluation of biocontrol agents against $C$.gloeosporioides- (Dual culture technique)

\begin{tabular}{|c|c|c|c|}
\hline T. No. & Bioagents & $\begin{array}{c}\text { Mycelial growth of } \\
\text { pathogen }(\mathbf{c m})^{*}\end{array}$ & $\begin{array}{c}\text { Percent inhibition } \\
\text { over control (\%) }\end{array}$ \\
\hline $\mathrm{T}_{1}$ & Pseudomonas fluorescens 1 & $5.33^{\mathrm{b}}$ & 40.77 \\
\hline $\mathrm{T}_{2}$ & Bacillus sp & $4.03^{\mathrm{c}}$ & 55.22 \\
\hline $\mathrm{T}_{3}$ & Trichodermaviride & $2.93^{\mathrm{d}}$ & 67.44 \\
\hline $\mathrm{T}_{4}$ & Trichodermaharzianum & $2.50^{\mathrm{e}}$ & 72.22 \\
\hline $\mathrm{T}_{5}$ & Control & $9.00^{\mathrm{a}}$ & 0.00 \\
\hline \multicolumn{2}{|c|}{$\mathrm{CD}(\mathrm{P}=0.05)$} & 0.57 & \\
\hline
\end{tabular}

Table2. Efficacy of botanicals on the growth of $C$.gloeosporioidesin vitro5\% and $10 \%$ Concentration

\begin{tabular}{|c|c|c|c|c|c|c|}
\hline Treatment & Common name & $\begin{array}{l}\text { Parts } \\
\text { used }\end{array}$ & $\begin{array}{l}\text { mycelial } \\
\text { growth } \\
(\mathrm{cm}) *\end{array}$ & $\begin{array}{c}\text { Per cent } \\
\text { inhibition } \\
\text { over } \\
\text { control }(\%)\end{array}$ & $\begin{array}{l}\text { mycelial } \\
\text { growth } \\
(\mathrm{cm}) *\end{array}$ & $\begin{array}{c}\text { Per cent } \\
\text { inhibition } \\
\text { over } \\
\text { control }(\%)\end{array}$ \\
\hline & & & \multicolumn{2}{|c|}{$5 \%$ concentration } & \multicolumn{2}{|c|}{$10 \%$ concentration } \\
\hline $\mathrm{T}_{1}$ & Prosphis & Leaf & $6.16^{\mathrm{d}}$ & 31.55 & $6.03^{\mathrm{d}}$ & 33.00 \\
\hline $\mathrm{T}_{2}$ & Pungam & Leaf & $5.26^{\mathrm{e}}$ & 41.55 & $5.03^{\mathrm{e}}$ & 44.11 \\
\hline $\mathrm{T}_{3}$ & Garlic & Bulb & $3.90^{\mathrm{g}}$ & 56.66 & $3.36^{\mathrm{g}}$ & 62.66 \\
\hline $\mathrm{T}_{4}$ & Ginger & Rhizome & $24.66^{\mathrm{f}} 64$ & 7048.88 & $4.53^{\mathrm{f}}$ & 49.66 \\
\hline $\mathrm{T}_{5}$ & Bougainvillea & Leaf & $7.13^{c}$ & 20.77 & $6.73^{c}$ & 25.22 \\
\hline $\mathrm{T}_{6}$ & Neem & Leaf & $6.03^{\mathrm{d}}$ & 33.00 & $5.80^{\mathrm{d}}$ & 35.55 \\
\hline $\mathrm{T}_{7}$ & Onion & Bulb & $8.36^{\mathrm{b}}$ & 7.11 & $7.86^{\mathrm{b}}$ & 12.66 \\
\hline $\mathrm{T}_{8}$ & Tulsi & Leaf & $8.06^{\mathrm{b}}$ & 10.44 & $7.60^{\mathrm{b}}$ & 14.44 \\
\hline $\mathrm{T}_{9}$ & Coleus forshikohli & Leaf & $7.16^{\mathrm{c}}$ & 20.44 & $6.90^{c}$ & 23.33 \\
\hline $\mathrm{T}_{10}$ & Coleus forshikohli & Rhizome & $6.13^{d}$ & 31.88 & $5.83^{d}$ & 35.22 \\
\hline $\mathrm{T}_{11}$ & \multicolumn{2}{|l|}{ Control } & $9.00^{\mathrm{a}}$ & 0.00 & $9.00^{\mathrm{a}}$ & \\
\hline \multicolumn{3}{|c|}{$\mathrm{CD}(\mathrm{P}=0.05)$} & 0.60 & & 0.47 & \\
\hline
\end{tabular}

*Mean of three replications

The treatment means are compared using Duncan Multiple Range Test (DMRT).

In a column, means followed by a common letter $(\mathrm{s})$ are not significantly different $(\mathrm{P}=0.05)$. 
International Journal of Trend in Scientific Research and Development (IJTSRD) ISSN: 2456-6470

Table3. In vitro evaluation of fungicides against $C$.gloeosporioidesat0.1\% and $0.2 \%$ concentration (Poison food technique)

\begin{tabular}{|c|c|c|c|c|c|}
\hline Treatment & Fungicide & $\begin{array}{c}\text { Mycelial } \\
\text { growth }(\mathrm{cm}) \\
*\end{array}$ & $\begin{array}{c}\text { Per cent } \\
\text { inhibition } \\
\text { over control } \\
(\%)\end{array}$ & $\begin{array}{l}\text { Mycelial } \\
\text { growth } \\
(\mathrm{cm}) *\end{array}$ & $\begin{array}{c}\text { Per cent } \\
\text { inhibition } \\
\text { over control } \\
(\%)\end{array}$ \\
\hline & & \multicolumn{2}{|c|}{$0.1 \%$ concentration } & \multicolumn{2}{|c|}{$0.2 \%$ concentration } \\
\hline $\mathrm{T}_{1}$ & Hexaconazole $5 \%$ EC & $1.13^{\mathrm{g}}$ & 87.44 & $1.03^{\mathrm{e}}$ & 88.55 \\
\hline $\mathrm{T}_{2}$ & Propiconazole $25 \%$ EC & $0.00^{\mathrm{h}}$ & 100 & $0.00^{\mathrm{f}}$ & 100 \\
\hline $\mathrm{T}_{3}$ & $\begin{array}{c}\text { Metalaxyl } 4 \%+ \\
\text { Mancozeb } 64 \% \text { WG }\end{array}$ & $7.63^{\mathrm{c}}$ & 15.22 & $7.23^{\mathrm{c}}$ & 19.66 \\
\hline $\mathrm{T}_{4}$ & Azoxystrobin $23 \%$ EC & $7.33^{\mathrm{d}}$ & 18.55 & $7.03^{c}$ & 21.88 \\
\hline $\mathrm{T}_{5}$ & $\begin{array}{c}\text { Tebuconazole } 50 \%+ \\
\text { Trifloxystrobin } 25 \% \\
\text { WG }\end{array}$ & $1.40^{\mathrm{f}}$ & & $1.20^{\mathrm{e}}$ & 86.66 \\
\hline $\mathrm{T}_{6}$ & Carbendazim $50 \% \mathrm{WP}$ & $8.63^{b}$ & 4.11 & $8.60^{\mathrm{b}}$ & 4.44 \\
\hline $\mathrm{T}_{7}$ & Mancozeb $75 \% \mathrm{WP}$ & $3.23^{\mathrm{e}}$ & 64.11 & $2.90^{\mathrm{d}}$ & 67.77 \\
\hline $\mathrm{T}_{8}$ & $\begin{array}{c}\text { Carbendazim } 12 \%+ \\
\text { Mancozeb } 63 \% \mathrm{WP}\end{array}$ & $1.20^{\mathrm{g}}$ & 86.66 & $1.10^{\mathrm{e}}$ & 87.44 \\
\hline $\mathrm{T}_{9}$ & Control inte & $9.00^{\mathrm{a}}$ & 0.00 & $9.00^{\mathrm{a}}$ & 0.00 \\
\hline & $\mathrm{CD}(\mathrm{P}=0.05)$ & 0.46 & tentitic & 0.41 & \\
\hline
\end{tabular}

*Mean of three replications

The treatment means are compared using Duncan Multiple Range Test (DMRT).

In a column, means followed by a common letter ( $\mathrm{s})$ are not significantly different $(\mathrm{P}=0.05)$. 